\title{
薬学教育における科学英語の習得：企画と体制の必要性
}

\author{
Foo Wah Foong ${ }^{\dagger}$
}

\section{Acquiring Science English: A Plan and System Are Needed}

\author{
Foo Wah Foong ${ }^{\dagger}$ \\ Department of English for Pharmaceutical Science Communication, Kyoto Pharmaceutical \\ University; 5 Nakauchi-cho, Misasagi, Yamashina-ku, Kyoto 607-8414, Japan.
}

(Received May 17, 2017)

\begin{abstract}
Literary English is different from science English (SE) and pharmaceutical science English (PSE). Therefore, a totally new approach was adopted for students to learn PSE at Kyoto Pharmaceutical University (KPU). In 2012, a 4year program for teaching PSE was proposed, and a stepwise-stepup tertiary science English education (SSTSEE) system was introduced at KPU. The system provides a novel form of PSE teaching that stretches from year 1 to 4, where the PSE level progresses to higher levels of learning with each passing academic year. With the launch of the SSTSEE system, relevant science-educated staff were provided with training and were also requested to study the syllabi of the respective academic years to write textbooks with the appropriate PSE content for their respective levels. From 2012 to 2015, textbooks and curricula for 4 year academic levels were developed and published to meet the needs for PSE learning at each academic level. Based on results of the SSTSEE system, year 1 students acquired the SE basics, and year 2 students applied the SE basics acquired. In years 3 and 4, students further pursued and developed their PSE ability. Additionally, students participated actively in developing skills in the reading, listening, writing, and speaking of SE/PSE. Active-plus-deep learning prompted students in developing those skills using illustrations, posters, and power-point slideshow presentations. By year 4, average achievers had established an independent level of competency in reading, listening, speaking, and writing PSE. Moreover, the SSTSEE system accommodated students timely in developing communication skills for practical fieldwork (clerkships) at pharmacies/hospitals in year 5 and for their future endeavors.
\end{abstract}

Key words_— stepwise-stepup education; science English; education system

\section{背景}

京都薬科大学の薬学英語教授に就任してこの方, 2017 年 4 月で 7 年が経過した。近年，私は若くて 急成長する学生の二ーズについて多くのことを学 び，潜在的に古くて価值があるものの非効率的なプ ログラムであったものに新しい血を注入することが できた。 また，そうしたことが，学問分野のグロー バル化の推進や理解を深めることに影響を与えるで あろうことを希望している.

学会でお会いする年配の日本人科学者や教育者

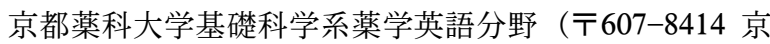
都市山科区御陵中内町 5)

現所属：†イメックスジャパン株式会社語学研究部門 (干603-8425 京都市北区紫竹下緑町 22-8 イメックス ジャパンビル 3F)

e-mail: 78imexfw@gmail.com

本総説は, 平成 28 年度退職にあたり在職中の業績を中 心に記述されたものである。
が，日本で行われている教育プログラムに従い，少 なくとも 8-9 年間（中学で 3 年，高校で 3 年，大学 で 2-3 年）英語を学習しているにもかかわらず，日 本の院生や研究者の国際的コミュニケーション能力 不足1を嘆いているのを度々耳にした。

最近，すべての小学校で英語が導入されたが，結 果が出てくるのはまだ先のことである，従来の日本 の英語教育システムは，主として入試に合格するこ とに焦点が当てられているため，日本人学生は，一 般英語及び科学英語の両方についてコミュニケー ションとしての英語能力に課題を抱えていると言え る. ${ }^{2)}$ また，彼らは書くことにはある程度力量があ るが，口頭でのコミュニケーションに弱点があるこ とは疑いの余地がないように思う。さらに言えば, 彼らが 8-9 年で学ぶ英語は, 一般英語であり，科 学・薬学英語 (pharmaceutical science English; PSE) ではない, PSE は, 理解, 学習, 及び高度な特異性 
を有する多様な専門的術語を含んでいる術語，表現 及び材料 ${ }^{3-6)}$ が通常の一般英語とは，かなり異なる ため，学生達が，PSEを学ぶには，新しいアプ ローチが採用される必要があつた。つまり，自然界 が，私たちにどのように見えるかについて，体系づ けて説明することのほかに, 科学英語 (science English; SE) は, 観察結果, 理由付け, 評価, 分析デー 夕の表現，及び科学を指向した分野における日常的 意思疎通に必要とされる特殊な目的を持つタイプの 英語（English for special purpose; ESP） であり，同 時に専門用語及び科学的概念や発見したことの伝達 に関する典型的表現の機能を有している. ${ }^{1,7-9)} 1992$ 年からずっと，私は，日本の科学技術教育の中での $\mathrm{SE}$ の概念の理解に焦点を当てようと努力してき た．京都大学を除いて，多くの学校は，それに無関 心であった。

国際学会で演壇に立つ日本人科学者がつらい思い をしているのを見ることが多々あったが，もし彼ら が，聴衆からの質問を正しく理解する聞き取り能力 を有し，SE を用いて効果的に応答することが可能 であったならば，そんなに悩むこともなかったのか もしれない. 当時私は, 京都大学で行動薬理学及び 電気生理薬理学の学位取得に従事する学生であった が，若手日本人科学者が SE をもつと効果的に使う 手助けをするために, 卒業後に何かしたいと思っ た．しかしながら，当時の私は，人体に対する薬物 の作用に興味があったので，オーストラリアの国立 キャンベラ大学にてポストドクとして働いた。その 後 2 年間, マレーシア大学 (Malaya University) の医学部で教鞭をとり，ついで日本の製薬会社に就 職したが，マウスやラット及びラビットのような柔 毛動物に対するアレルギーのために退社を余儀なく された，次の職場としては，動物実験室でないとこ ろが第一選択肢であったが，もう少しチャレンジし てみたいと思った，そこで，院生の頃に考えたよう に，若手日本人科学者に私の学んできたすべてのこ とを教えてみたいと思った。このようにして，1992 年に恩師の佐藤正道教授（当時，京都大学薬学部研 究科長）からお話を頂いたことが契機となり，最初 に, 京都大学薬学部にて非常勤講師として SE を教 え始めた。当時, SE として英語を学ぶ学生にとつ て，適切と思われる教科書は，私からみて皆無で あった。したがって，中等及び高等レベルの学生が
勉強するための英語の教科書をゼロからつくる必要 があった。

\section{科学英語の教科書作成}

私が，京都大学で初めて SE・PSE を教え始めた ときには，教材を部分的にコピーして学生に配布し たが，関連する他の内容の説明に時間を浪費するこ とが多々あった。学生が SE・PSE をもつと効率よ く学ぶためには，専門用語の発音，数，単位，数 式・化学式の読み方及び SE・PSE における表現を 記載したテープ（現在はディスク）付きの教科書を 用いて彼らの視聴覚を訓練することが必須であると いう考えに至った。

日本人学生の一般英語及び SE・PSE の能力不足 を痛感することになったので，日本で薬理学を専門 的に追及してきたことは幸いであった，例えば，小 数点付きの数字, 定量的単位, 化学元素・化合物, 数式・化学反応式，その他の SE・PSE における正 しい読み方等について，日本の大学院生があまりに も知らないことに驚いた。 そこで，私は，学生達が $\mathrm{SE} \cdot \mathrm{PSE}$ を学ぶための教科書を書くプロジェクト に取り掛かった。その結果，SE・PSEを教えた り，学習したりするための教科書の 1 冊目10) を作成 した，学生が，発音の間違いを再学習するために録 音テープ・CD もまた，実用的学習の戦略的ツール であった。

印刷については，種々の困難があつたが，1995 年に, 私は Imex Japan 株式会社のサポートの下に 何とか教科書の出版にこぎつけた。“Useful Scientific English”という表題の第一版は，その後，改訂 され，今では“Comprehensive Scientific English”'10) となっており, 京都大学と大阪薬科大学において今 なお使われている．また，他のべテラン科学者とと もに新たな教科書を作成し，年を追うごとに何冊か の SE・PSE 関連の教科書を出版した。私の $\mathrm{SE}$ ・ PSE 教育を支持してくれた多くの読者や教育者の お陰で, 10 冊の SE/PSE 関連の教科書を出版する ことができた. ${ }^{10-19)}$

\section{時機到来}

京都大学で非常勤講師をしているうちに，私の $\mathrm{SE}$ ・PSE 教育法の有用性及び効率のよさが関西で 知られるようになり，その結果，多くの薬学部・医 学部から SE・PSE を教えるポジションを提供され た。 2006 年 4 月には, 日本の 6 つの大学の 7 学部 


\section{The SSTSEE System}

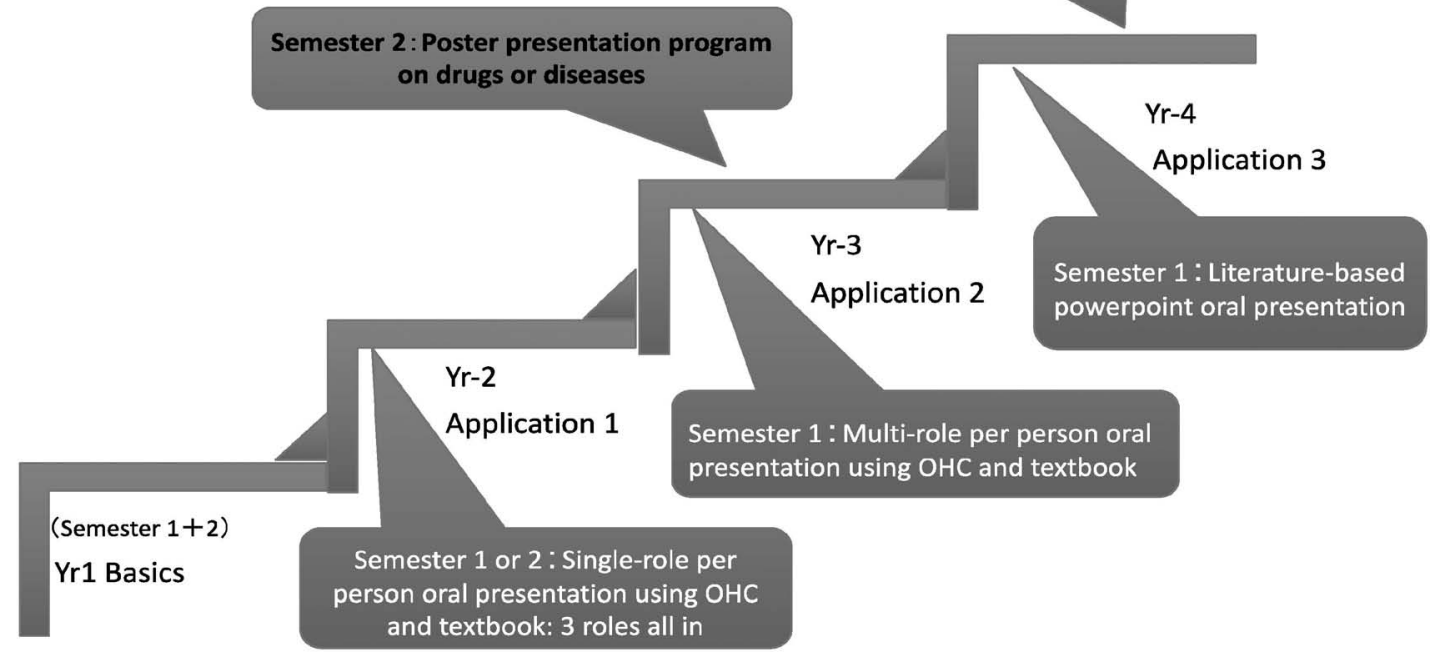

Fig. 1. The Stepwise-stepup Tertiary Science English Education (SSTSEE) System Designed for Non-native English Learners to Acquire Pharmaceutical Science English

で教えた．ある学部で包括的な SE コースを大学院 に入る前の学生に提供しようと思ったが，非常勤で 教えている間は，実現は困難であった。

私が，京都薬科大学の $\mathrm{SE} \cdot \mathrm{PSE}$ 教育の正規職員 に応募したのは 2009 年の 12 月であった. ${ }^{20)}$ 京都薬 科大学は，ちょうど SE・PSE 教育の正規職員採用 を考えていたこともあり，2010 年に特別に開設予 定の講座の主任教授に任命されることになった。

\section{準備時期}

1997 年より前のことであったが， 1 年次生と 2 年 次生のための教育カリキュラム及び教育材料が再度 選定されることになり，PSE とは無関係ではある が複数の評判のよい科学的内容の教科書から，その 内容が部分的に採用された。生命科学，薬学及び医 学分野に関する SE を基礎とする知識を 1 年次生の 教育内容として配し，ついで高学年に移行するにつ れて，内容を深めることに焦点を当てることは，よ い考えであると思った. ${ }^{19,20)} 2010$ 年には, 薬剤師を 育成する目的で 1 年次生のための標準的教科書 ${ }^{10)}$ を 使用する講義が始まった．学年が進むにつれて科学 的思考や SE・PSE 使用においてスキルアップでき るような内容であった。このようにして，薬局ある いは病院での相談・調剤に関するPSEが翌年 （2011 年）京都薬科大学の 2 年次生の教科として導 入された. ${ }^{13)}$ その間，私は，引用された教科書 ${ }^{14)}$
使用して, 科学論文の書き方について大学院生に講 義をし，また公表論文を使用した研究結果の口頭発 表の講義を行った。

大学カリキュラムの改定：PSE 教育一学習システ 么の確立

2012 年に始まった 6 年制薬学教育プログラムを 受け，大学カリキュラムの改定の必要があり，PSE 教育の 4 年にわたる教育プログラムを提案した。先 見の明をもって，京都薬科大学は，私の提案を受け 入れてくれ，私の新構想である「総合的 PSE4 年教 育一学習プログラム」が，定着し始めた。

他の教授からのフィードバックと助言によって, 新規システム (i.e., stepwise-stepup tertiary science English education; SSTSEE) ${ }^{21)}$ が，京都薬科大学の 学生を教育及び育成する今後の取り組みのために特 別に設けられた（Fig. 1)。本システムは，日本で も他の非英語圈でも前例がなかったものである，そ の後, 6 年次生による卒業論文の研究結果を発表す る際にPSE の使用が計画され，間もなく大学当局 によって実現された。

\section{SSTSEE システム ${ }^{21)}$}

本教育プログラム「SSTSEE システム」は，1-4 年次生にわたる SE・PSE 教育が体系的に構成され ており，PSE のレベルは，低学年から高学年へと 学年を追うごとに進歩する。まず， 1 年次生は， $\mathrm{SE}$ 
あるいはPSE の基礎について学ぶ.

これらの基礎22-32) は，数字，単位, ${ }^{22)}$ 形，大き さ, 及び寸法, ${ }^{23,24)}$ 数式・化学式・相関関係を表現 すること, ${ }^{25-27)}$ 化学元素名, 有機/無機化合物, 反 応25-27)の記述，ギリシア語及びラテン語28) 由来の科 学用語の理解及び命名, 薬品の物理的/化学的性質 を理解/記述する SE/PSE 文法及び語彙, ${ }^{29-32)}$ すな わち, 英語圈において, 大学入学許可レベルで習得 する内容 [Basic Scientific English IA ${ }^{15)}$ (for PSE-1A) \& IB ${ }^{16)}$ (for PSE-1B)] を含んでいる.

1 年次で習得したことを基礎として，2 年次生は, 2 年次の内容, すなわち生命科学の基礎（photosynthesis, respiration, carbohydrates, lipids \& proteins; nucleic acids \& the genetic code; the cell, bacteria \& viruses), 化学 (IUPAC system; types of chemical reactions \& chirality), 及び物理 $\left(\mathrm{pH}\right.$ and $\mathrm{p} K_{\mathrm{a}}$; radioactive decay \& radioisotope）を構成するトピッ クについて，同僚の前で口頭発表をする際にこれら のスキルを応用することを求めた．本アプローチ は，学生が，相当する学年において日本で教えられ る内容と範囲が類似した教材 [Useful Pharmaceutical Science English (for PSE-2)]17)での学習を可能 にすることにつながる. 3 年次生になった際には, 彼らは, 前期で基礎有機化学, 食品添加物及び防腐 剂, 消化管システム, 循環器システム, 薬物投与, プロスタグランジン，ロイコトリエン，プロスタノ イド，新薬創製，ヒト免疫不全ウイルス，重症急性 呼吸器症候群, 代謝疾患, アルツハイマ一病, 生薬 療法, 漢方, 核医学, $\mathrm{X}$ 線及びイオン及び電子を 含む教科書 [Practical Pharmaceutical Science English (for PSE-3A) ] 18) の内容をスライド作成してロ 頭発表する必要がある.

3 年次の後期（PSE-3B）では，学生はポスター を使用して, 研究結果を発表することを学ぶ、口頭 発表のテーマは, 疾病と薬物, すなわち疾病の背景 及びタイプ, 症状の特性, 感染ルート, 病因, 治療 及び予防に関連するものである。薬物を使用する治 療には，薬物の作用機序，適応症，投与量と投与計 画，投与経路，有害反応，禁忌等が含まれる.

4 年次の前期（PSE-4A）では，学生は，学術誌 に公表された科学論文を用いて口頭発表を準備し, パワーポイントスライドを使用して論文の特定箇所 について口頭発表を準備し，彼ら自身の間で内容を
分割するとともに，各自が責任をもつて発表を行う.

2 つのグループが同じ内容で発表することはな く, 学生は, 適切に, 概略図, 実例, 及び背景デー 夕等を示して発表する。 4 年次の後期 (PSE-4B) では, 学生は, 聞き取り用 CD 付きの教科書 [Basic English Communication for Pharmacists II (PSE4B）]13) を使用して，OTC 薬と処方箋薬についての 薬剤師一顧客/患者間のインタビューについて学ぶ. 顧客・患者に対するご挨拶，病気の兆候及び症状を 見い出すこと, 兆候・症状を可能性のある合併症と 関連づけること，薬剤投与計画について指示を与え ること, 薬物有害反応について顧客/患者に情報提 供すること，起こり得る物質アレルギー反応の チェック，コンプライアンスの促進，専門的アプ ローチ, 適切な言語, 心理学, 治療上の知識, 医療 上のノウハウ，薬物投与，薬物投与計画及び関連事 項 ${ }^{33-36)}$ に関する最適な医療及び効果的な治療の確保 におけるプロとしての助言を用いて禁忌等について 危険性に気付かせることを学ぶ。

口頭発表（2-4 年次）とは別に，PSE で使用され る文法及び特定の専門用語29-32) をカバーする筆記試 験（4 年次には筆記試験はない）及び PSE の和文 英訳を課する。広範なシラバスをカバーするため に，択一式問題と記述式問題の両方がプログラムに 取り入れられており，広範な知識と記述能力が日本 及び非英語圈の PSE 学習の究極のゴールとなる. 年が経つにつれて，2012 から 2015 年の SSTSEE シ ステム用の 1 年次, 2 年次, 3 年次, 4 年次におけ る SE・PSEの読み取り，聞き取り，書き取り，及 びスピーキングのための学習ツール ${ }^{19)}$ が作成され, 京都薬科大学において公表された。本学習ツール, 講義, 及びシステムは, その後設置され, 効果が現 れるには，熱意，協力，及び積極的な参画が必要で あった.

教育プログラムを成功させるためには，経験とス キルを持つ適切なスタッフが必要である。資格はあ るが PSE 教育の経験を欠くスタッフは，適切な時 期と場所で訓練が必要であった。 SSTSEE 21 システ ムを実行に移しつつ，私は，担当者を集めて全セメ スターを通した教え方の訓練を実施した。彼らは, 基本的には科学者（言語訓練を受けていなかったけ れども）であったので訓練は，それほど苦労するこ ともなかった，有能な講師の一団が，年月を経て成 
Feedback on subject

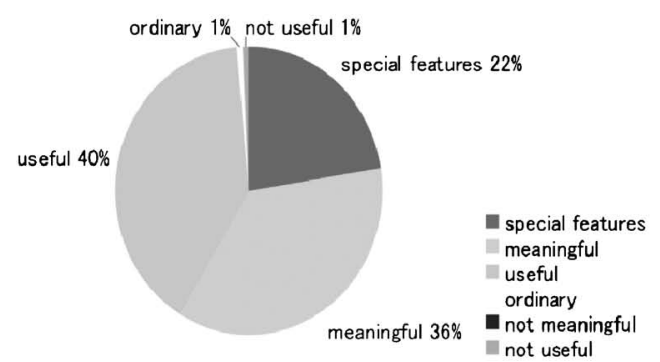

Feedback on teaching contents

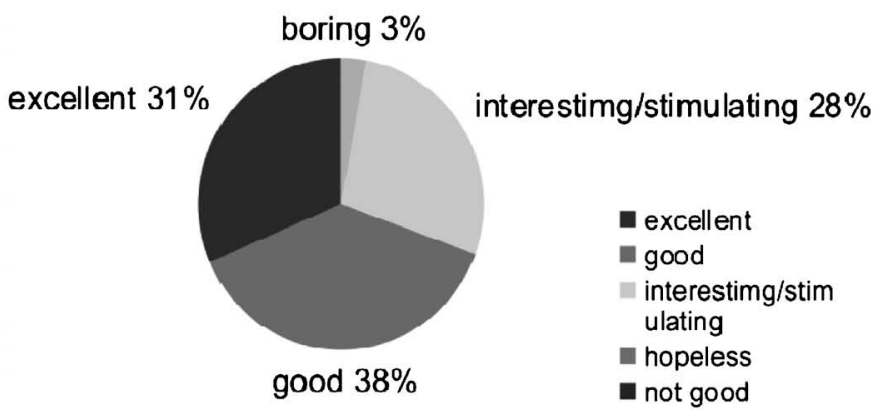

Fig. 2. Perception Feedback from Students at the End of Semester Using a Questionnaire Students exposed to PSE-based or SE learning for the first time exhibited much enthusiasm, proactive and affirmative feedback throughout Yr-1.

長してきた，すなわち各講師が，それぞれの学年の 学生の要望に応えられるように訓練された。先生方 は，さらに教科書 ${ }^{15-18)}$ を（各学年レベルのPSE を 用いて適切な内容で）書くために各学年の大学カリ キュラムのシラバスを研究する必要があった。 口頭 発表（2-4 年次）に加えて, PSE で使用される文法 及び特定の専門用語29-32) をカバーする筆記試験（た だし， 4 年次には筆記試験はない）及び日本語の内 容をPSE で表現する問題が課されたが，それには 択一式問題と記述式問題の両方が含まれていた. ${ }^{37)}$ 2012-2015 年には， 1 年次， 2 年次， 3 年次及び 4 年 次用の教科書 (聞き取り教材のあるものとないもの) が出版され ${ }^{13,15-18)}$, 京都薬科大学の学生に必要とさ れる学習ツール18)を提供することができた．京都薬 科大学で SE/PSE を教えるに際して，すべての学 年でマイクを使用したのは，発音の間違いを聞き 取ったり，然るべき訂正をするために極めて効果的 であり, 訂正に際して, マイクを使用することで, 全 員が正しい発音を聞くことができたからである. ${ }^{38)}$

\section{具体的なプログラムの内容と学生からの評価}

1 年次：前期の終わりに，学生からの意見を聞く アンケート（Fig. 2）を行った。 学生の評価は, 講 義前に比較して講義後には有意に高い点数であっ た. ${ }^{39,40)}$ 講義前の試験結果は，概して記述式応答に 弱点があることを示しており，また講義後に確立さ れた一貫性のある改善が有意であったことは興味あ る結果であった。このテストを受けた学生は，これ らの課題に取り組んでみることに興味を示した (Fig. 2, Right)。SE 学習に関するフィードバック (Fig. 2, Left) について, 学生の満足度は高いもの
であつた，学習した内容は，将来の薬学関連の理解 とコミュニケーションの改善という点から学術的に 有用であることが判明した。

2 年次 $: 2$ 年次 (シラバスの題目 : PSE-2) では, 1 年次で習得した SE の基礎を応用し, 同僚の前で PSE の内容を口頭発表する. ${ }^{37)}$ 教科書の内容に基づ く口頭発表 ${ }^{17)}$ (生命科学，化学及び物理で構成され る）が，2 年次の薬学英語教育において採用され た. 学生が同じ内容を日本語と英語の両方で学ぶ, つまり，ある特定の主題について日本語で学習する ことを，講義の間に PSEでも再学習することも チャレンジとして行われることになった.

グループに分けられた学生が，教科書の特定の一 節及び・又はセクションを読んで理解することを要 求される。各学生は, 発表において，3つの役割す なわち, 主たる内容の英語発表, 日本語での要約, 関連する説明図の表示（Fig. 3) を輪番制で実施す る.さらに，学生は，そのセクションに関連する更 なる情報の探索を要求される。講師は, 教科書の内 容を要約することによつて話題の理解を助け，文法

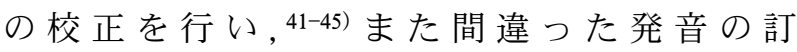
正 ${ }^{29-32,41-45)}$ を行う。発表の間, 聴き手 (聴衆) は, 英語での発表内容を要約する。 さらに, 各ユニット の終わりに，本ユニットを聴いている学生は，発表 に関する質問及び要約を書いて提出することを要求 される.

日本語の講義で理解できなかつたことを習得でき た（あるいはその逆）ことを学生から度々聞くこと は喜ばしいことであった。この日本語-PSE スタイ ルの総合学習は, 薬学に特化した学習を促進, 補完 


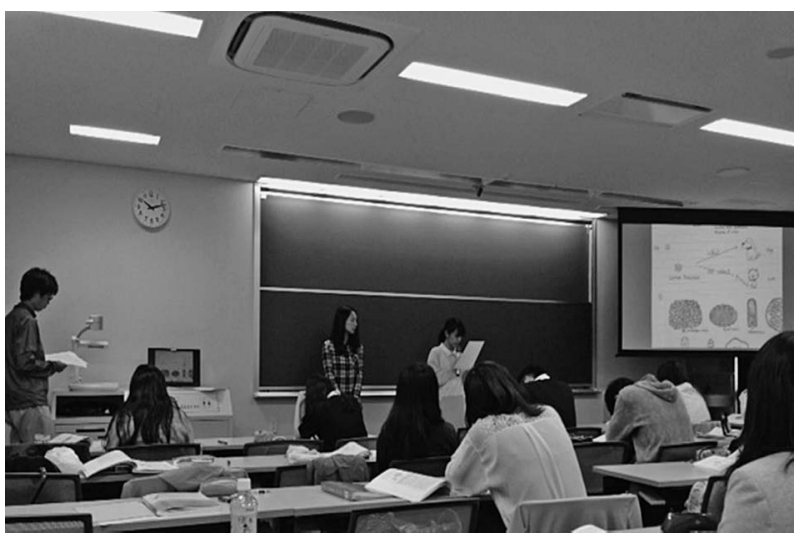

Fig. 3. Students Presenting Their Respective Sections in a Book as a Group

Each student plays 3 different roles (English presentation, Japanese summary, and showing visual aids or illustration) in a rotational system.

するものである. ${ }^{46)}$ 学生は, また同僚達の前で, PSE で理解したことを口頭発表することも学習し，その 結果，PSEを使用して人前で話すことに自信を築 くばかりでなく，読み取り，書き取り及び理解力を 育成することができる。聴衆については，口頭 PSE を聴き取ること，質問すること，理解したこ とを要約することを学び，このようにして，科学的 探究心 (探究的学習) と情報を受け取る能力を高め,

書き取って自らの理解を表現することを学ぶ. ${ }^{47)}$ 学 生は，生命科学，化学，及び自然科学のPSE を読 み取ったり，書き取ったり，聴き取ったり，話した りすることを学習する際に，互いに補助しあう。そ のため，学習過程やクラス全体の進歩が一丸とな る.このように，本 SSTSEE システムは，PSE 学 習において，「基本的ニーズ」，「創意工夫」，「チー ムワーク」,「情報検索」,「自信の構築」及び「人前 で話すこと」に力点を置いている．時間不足とクラ ス規模のために，学生間の質疑応答が， 2 年次では 省かれているけれども，Q＆A は， 3 年次と 4 年次 ではノルマである. 2 年次の学生評価では, 発表内 容（説明図の表示，情報の供給量），及びスキル (発音，声量，文法，流暢さ，説明図の提供）及び 筆記試験が，本科目に関する成績として反映され る. 学生からのフィードバックは, 希望を与えるも のであり，本アプローチが，学生にとっても教員に とっても価值があるものであった，さらに改善の余 地はあるけれども，特定の専門用語の発音及び PSE 表現が時間とともに改善するのを見ること は，本当にやりがいを感じることであった。
Table 1. Subject- and Content-related Items after Completion of Presentation Sessions (PSE-2)

\begin{tabular}{lrlr}
\hline \hline About the subject & $\begin{array}{c}\text { Count } \\
(\%)\end{array}$ & Presentation content & $\begin{array}{c}\text { Count } \\
(\%)\end{array}$ \\
\hline Specificity & $53(27.5)$ & Excellent & $24(14.4)$ \\
Useful & $54(28.0)$ & Interesting/Stimulating & $24(14.4)$ \\
Meaningful & $21(10.9)$ & Good & $88(52.7)$ \\
Ordinary/Challenging & $48(24.9)$ & Not good & $10(5.9)$ \\
Not meaningful & $10(5.2)$ & Hopeless & $0(0)$ \\
Not useful & $7(3.6)$ & Boring & $21(12.6)$
\end{tabular}

Table 2. Perception Feedback after Presentation (Yr-2): PSE-2

\begin{tabular}{|c|c|}
\hline Post-presentation feedback items & $\underset{(\%)}{\text { Counts }}$ \\
\hline $\begin{array}{l}\text { 1. I have learned to do oral presentation in } \\
\text { English }\end{array}$ & $41(27.2)$ \\
\hline $\begin{array}{l}\text { 2. I have learned certain skills in English presen- } \\
\text { tation }\end{array}$ & $16(10.6)$ \\
\hline $\begin{array}{l}\text { 3. I now have more confidence in speaking } \\
\text { science English }\end{array}$ & $14(9.3)$ \\
\hline 4. I have become a better person via group work & $38(25.2)$ \\
\hline $\begin{array}{l}\text { 5. I have learned to pronounce English words/ } \\
\text { numerals better }\end{array}$ & $39(25.8)$ \\
\hline $\begin{array}{l}\text { 6. I can understand science English better now } \\
\text { (via presentation) }\end{array}$ & $18(11.9)$ \\
\hline $\begin{array}{l}\text { 7. I have learned to summarize presentations by } \\
\text { others in English }\end{array}$ & $7(4.6)$ \\
\hline 8. I have learned nothing & $0(0)$ \\
\hline
\end{tabular}

発表セッションの終わりに，各クラスで，それぞ れ講師によってアンケートが実施された。168 の質 問のうちで, ratings of content and perception の有 効回答率は，それぞれ $98.2 \%$ 及び $90.0 \%$ あっ た。関連科目の肯定的認識 (high-level specificity, useful and meaningful) (Table 1) については, 合 計は $66.4 \%$ であった。普通認識は $24.9 \%$ で，否定 的認識 (not meaningful, not useful) は 8.8\%であっ た.

内容関連項目の肯定的認識 (excellent, interesting/ stimulating and good で構成される）については, (Table 1) 81.5\%であったが, 他方 not good, boring という否定的認識は $18.5 \%$ であった。発表後の認 識に対するフィードバックを提供した 151 名の学生 について項目 1-8 の各数（Table 2）は，最も頻度 の高い発表後の印象は, 学生が英語での口頭発表を することを学んだ後に, 発表を通して以前よりも PSE についての理解が深まったということであった. 

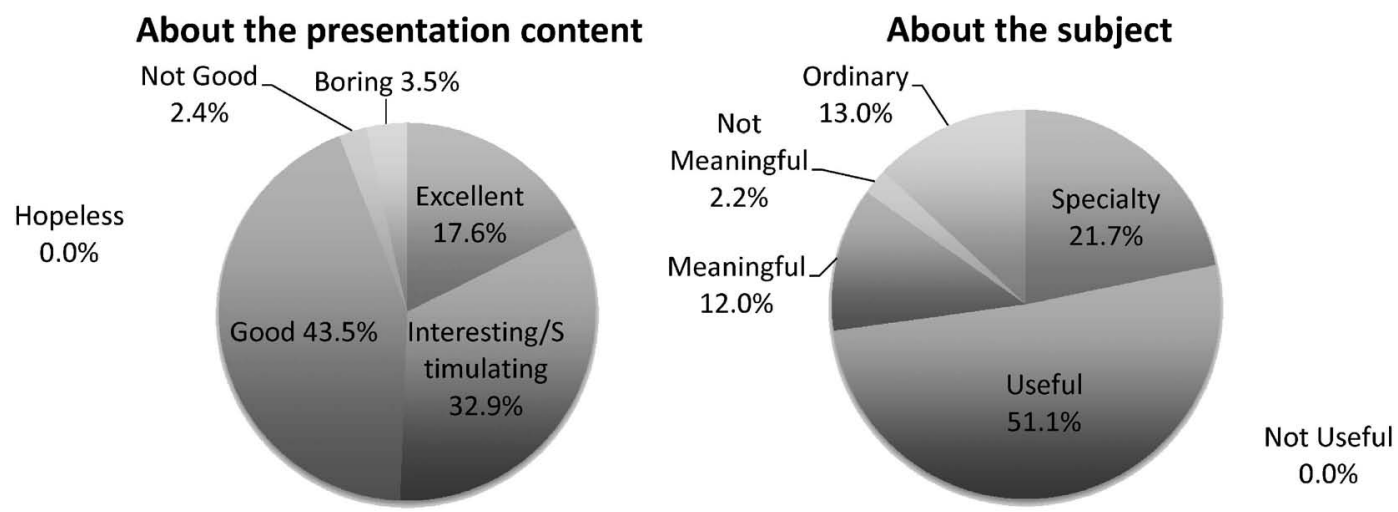

Fig. 4. Evaluation Yr-3 Students Made on Presentation Contents

Yr-3 students revealed that the presentation contents were: excellent, good, interesting and stimulating. Accordingly, the subject was: meanigful, useful, wirh speciality, and ordinary.

3 年次 : 学生は, 3 年次生になるまでに PSE コ ミュニケーションに参画するための基礎及び SE の 知識を自由に駆使できる十分な力を習得する. PSE に関して, さらに詳しく主題を学習するに際して彼 らを指導するために，2 年次のカリキュラムの続き として, 標準的教科書が 3 年次生前期 (PSE-3A) に採用される。学生（4-5人で構成される 9-10グ ループに分けられる) は，教科書（Practical Pharmaceutical Science English) ${ }^{18)}$ から 17 の話題の中の 1つを自由に選択でき，選択した話題の内容が，グ ループのメンバーの間で分担される。 2 年次 (active-plus-deep learning) と類似の方法46)で, 各学生 は読み取り, 理解し, そして責任を分担するセクシ ヨンについて更なる情報検索をする必要がある，各 講義は，1つの UNIT をカバーし，発表を聴き取る 側の学生は，発表された内容について質問し，要約 を書き取ったものを講義の終わりに提出しなければ

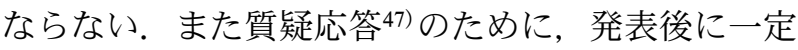
の時間が設けられる，聴き手が質問する際に，講師 は，用紙に質問を書き取り，スクリーンに映し出 し，すべてを見せることができる，質問文が間違つ ている場合には校正され，質問者が，それを声に出 して読み上げることになり，他の学生は校正された 質問を理解することができる，その間，講師は質問 者の発音をチェックする. ${ }^{41-45)}$ 理解を促進するため にフロアからの質問に答える以外に，発表する側の 学生は, 読夕取り, 書き取り, 理解, 情報検索を行 い，適切な説明図（参考文献から引用）を使用して 聴衆の理解を助ける努力をする，聴き手は，話の内 容を要約し，更なる理解を目指して質問をする

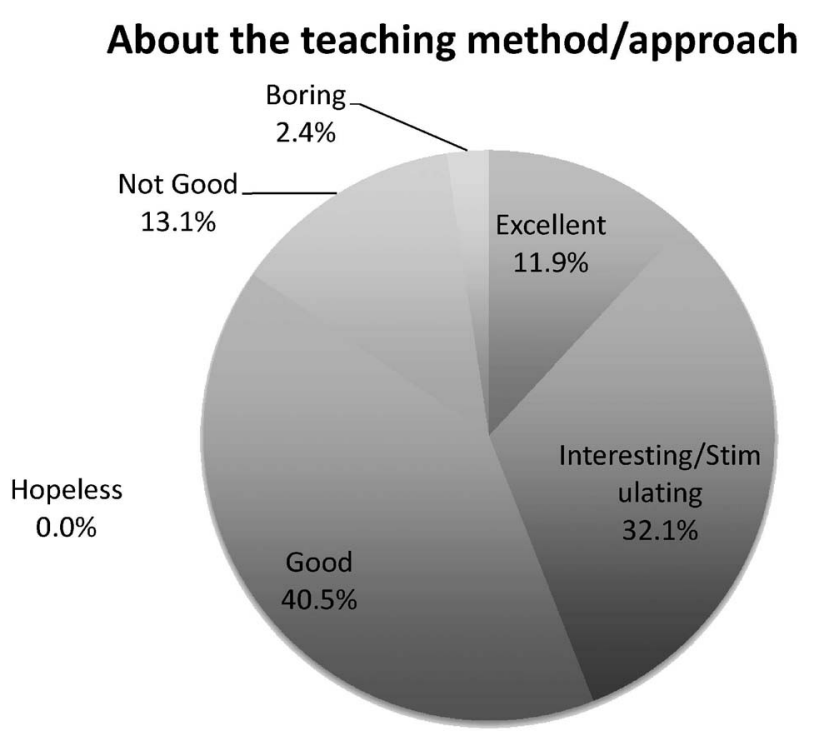

Fig. 5. Evalution Students Made on Teaching Method and Approach

Students found that teaching method and approach excellent, interesting and stimulating, as well as good.

(Fig. 4). その間，文法，内容，質問の質すべて が，経時的に向上したのは興味をそそる出来事で あった（Fig. 5)。学生の出来は，質疑応答，書式 の要約, 及び筆記試験で評価される.

3 年次の後期では（シラバスの主題 : PSE-3B), 学生はそれぞれ，グループあたり 4-5人の 9-10グ ループに分けられる.この学期では, 発表のための デザイン及びポスター作成について指導を受ける. 学生は, グループごとに集まり, 発表のためのテー マ選びに参画する。グループの意思決定は，チーム ワーク及び論理に基づいた意思決定を育成するため に役立つ。発表のテーマは, 病気の背景やタイプ, 


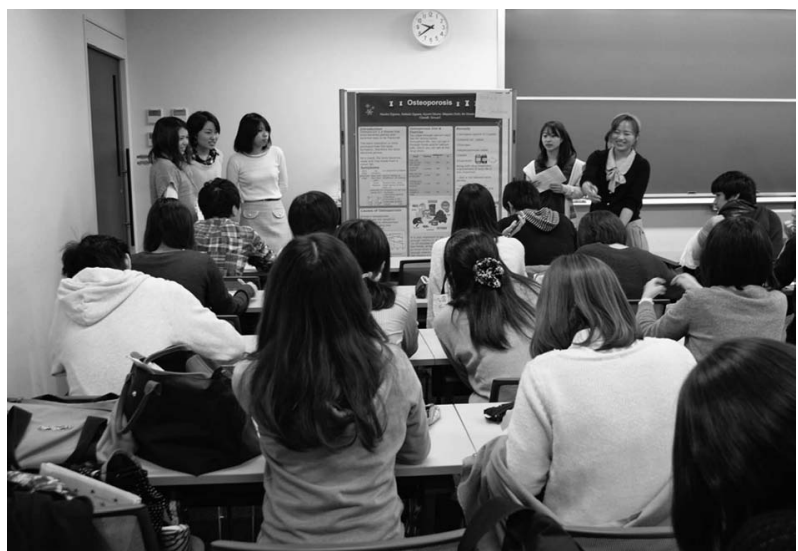

Fig. 6. Students Performing Oral Presentation Using a Selfdesigned Poster as a Group

Each student takes turn to do his/her respective sections with questions from the floor after presentation.

典型的兆候及び症状，感染ルート，病因，治療，薬 物及び予防等，病気や薬に関連する話題で構成され ている．医薬品を使用する治療については，適用， 容量用法，作用機序，型通りの投与ルート，薬物の 有害反応，及び禁忌等が，発表に含まれている。一 度，話題選びが済んだら，学生たちは，ポスター作 成を分担する，学生は，それぞれ，分担された箇所 の発表及び質疑応答に責任を持つことになる，予習 として，各グループは，最低一度は集まって，ポス ターを使用する口頭発表の練習をすることを義務付 けられ，その後，自らお互いに質問し，本番前に担 当箇所及び話題の理解を共有する．発表日には，各 グループは，自作のポスターを用いて，発表し，聴 き手が発表後に質問をする（Fig. 6)。この方法は, 学生の自信と自発性を開発するためにとても重要で ある、グループで作成するポスターのほかに，クラ スの各学生は, 個人用に, もう 1 つ別の内容のポス ターを作成して提出することを課される．個人用ポ スターは, グループとしてのものや他人によって発 表された内容に一致，あるいは類似したものであっ てはならない。学生の成績は，発表技術と発表内 容，すなわち，各ポスターの要約，発表，ポスター のデザイン・内容，質疑応答，及び個人用ポスター の点数に基づいており，この講義では，筆記試験は 行わない。この一連の講義の目標は, 病気と薬の知 識の共有，チームワークの育成，論文の読み取り及 び理解，トピックを理解するための戦略，研究結果 の要約, 質疑応答の適切な取り扱い, 情報検索能力 の育成などである，アンケートによると，学生たち

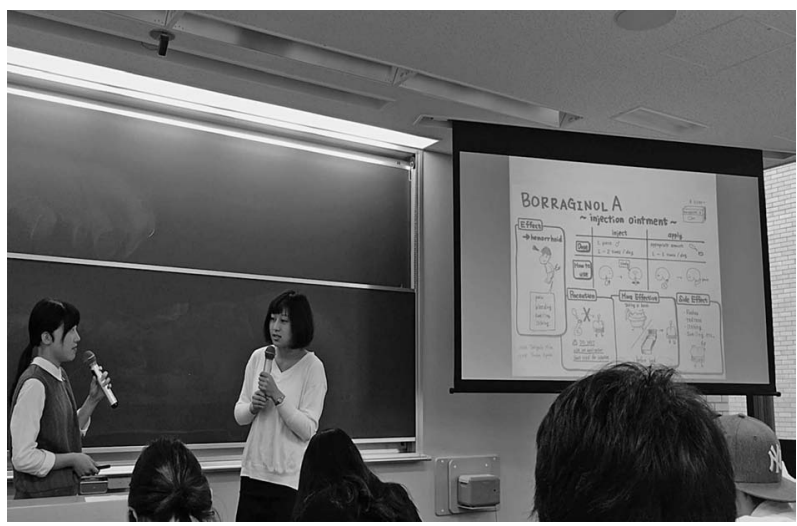

Fig. 7. Students in Pairs Performing Role-play Presentation of OTC in This Case

They are also required to role-play interview of dispensing prescription drug using visual aids such as illustrations (shown in upper right).

は，ポスターのデザイン，研究結果の包括的理解， 質疑応答，チームワーク育成などを学習できている ことが確認できる.

4 年次 : 4 年次の前期（PSE-4A）において, 学 生たちは，以前と同様，4-5人の発表グループに分 けられ，学会発表と同様に発表したり，質疑応答を 行う.47)さらに，必要な場合には，説明図を作成す る．何人かは，自分たちが作成した原稿を読みあげ ているものの，この時点で，学生たちは，背景とな るコンセプト, 方法, 結果, 議論, 及び結論を視覚 教材に言及することによって説明の質を向上させ る。学生の評価は，発表技術・内容（上記参照）, 聴き手作成の要約，及びスライドのデザインの平均 点に基づいて行う。この学期では筆記テストは行わ ない.

後期では，SSTSEE システムは，薬局で OTC 薬 を購入する顧客との意思疎通の仕方を学び，同様に 薬局あるいは病院で処方箋薬の調剤を実施する（シ ラバスの表題 : PSE-4B) 際に，患者にインタビュー したり，助言を与えたりすることをロールプレーで 学ぶ (Fig. 7)。5 年次の薬局や病院での実習の前 に，薬剤師と顧客あるいは患者に関する種々の状況 でのコミュニケーション技術と心理学的スキルの学 習が必要であるが, この学期の終わりまでには，学 生は，薬の調剤や治療に関する相談に必要な基本的 な専門用語を学んでいることになる。薬局での OTC 購入のためのインタビュー，あるいは薬局や 病院で実施される調剤での薬剤師と患者とのインタ ビュー等, ${ }^{33-36)}$ 種々の状況でのコミュニケーション 
において，学生は，再び教科書13)をフォローする. 14 回の講義の中には, 聴き取り, 異なる事例研究 について発表することが含まれる。 さらに，学生た ちは，OTC 薬の購入，及び処方箋に基づく調剤に 関する事例研究を使用して集中的に意思疎通のスキ ルを習得することを要求される.

薬剤師と顧客・患者の役割を演じることのほか に，学生たちは，読夕取り，理解，また病因学的背 景, 症状, 適応及び治療, 薬の作用, 投与量と投与 計画，コンプライアンス，薬物の有害反応，合併 症，及び禁忌を各事例研究に入る前の適切な時期と 場所で説明図を使用して発表する。学生たちは，ペ アを作って，講義室の前に行き，説明図を用いて指 定された病気及び・又は処方箋について関連する ロールプレーを身振り手振りで演じる，学生は，意 思疎通のスキル，発表のスキル，ロールプレーの内 容，与えられた状況で必要とする知識，人間関係に ついての理解，心理学的スキル，及び金銭上の事柄 等を使いこなす能力について評価される。この学期 では筆記試験はない。学生からのフィードバックで も，使用された教材を高く評価し，調剤の基礎や専 門用語の習得に満足した結果が示されている（Table 3).

\section{考察}

1 年次：講義後の結果（Fig. 2) は，学生は，適 切な教材15,16,39,40) を使用して, SE の内容（Fig. 2, Left）の有意な改善を達成し，その結果，SEの基 礎は適切な指導の下に, 適切な学習教材を用いれ ば，効果的に習得することが可能であることを示し
ている，さらに，彼らのフィードバック（Fig. 2, Left）によると，初めて SE 学習を経験した学生 は，能動的学習に著しい熱意と前向きな態度を示し た。本 SE 学習プログラムは，学生たちの熱い フィードバックを受けた。

2 年次 : このプログラムで 2 年次に入る前に, ほ とんどの学生は, 1 年次で基礎的な SE を学んでい たものの，英語での発表経験は全くなかった．報告 された彼らの受け止め方（Table 1）を見ると，合 わせて $66.4 \%$ の学生が，本発表が有用で有意義で あったと評価している。発表内容（Table 1）につ いては, 81.5\%が, この結果を excellent, interesting・stimulating, and good, と好ましいと受け止め ていたが, not good (5.9\%) 又は boring (12.6\%) という不満もあった。同じ内容を繰り返し教えられ た場合，あるいは十分にこの内容を知っていると 思った場合には，退屈と思う学生が出てくるが，学 生が，ぞうしてこの内容が boring or not good と回 答したのか確かめるための更なる研究が必要である.

7 つの肯定的な発表後のフィードバック項目（Table 2）によると，学生は，講師による従来の一方 的な講義すなわち受け身の講義よりもより多くのも のを得たと実感している.

3 年次 : 前期の学生からのフィードバック (Figs. 4 and 5) は, 元気づけられるものであり, 本講義 は，学生にとって有用であり，講師にとってもやり 甲斐のあるものであった，文法，質問の質，特定の 専門用語（PSE）の発音，及び英語表現が時間とと もに改善されることが分かったことは本当にやり甲

Table 3. Perception Feedback after Role-plays (Yr-4: PSE-4B)

\begin{tabular}{|c|c|c|c|c|c|c|}
\hline Item & Description & Poor & Fair & Good & Excellent & $\begin{array}{c}\text { Average } \\
\text { scores }\end{array}$ \\
\hline 1 & 科目の有用性（usefulness of subject/lectures） & 1 & 2 & 3 & 4 & 3.01 \\
\hline 2 & 適切な教材（textbook/teaching material） & 1 & 2 & 3 & 4 & 3.00 \\
\hline 3 & 専門用語の学習 (acquisition of technical terms) & 1 & 2 & 3 & 4 & 3.06 \\
\hline 4 & 英語で「考える」能力 (ability to think in English) & 1 & 2 & 3 & 4 & 2.75 \\
\hline 5 & 英語で「書く」能力（ability to write in English） & 1 & 2 & 3 & 4 & 2.70 \\
\hline 6 & 英語で「話す」能力（ability to speak in English） & 1 & 2 & 3 & 4 & 2.84 \\
\hline 7 & 質問を作成し, 行う能力（ability to construct and ask questions） & 1 & 2 & 3 & 4 & 2.72 \\
\hline 8 & 質問に対応する能力（ability to handle/answer questions） & 1 & 2 & 3 & 4 & 2.67 \\
\hline 9 & 人前で話すことに対する自信（confidence in public speaking） & 1 & 2 & 3 & 4 & 2.90 \\
\hline 10 & 薬物／疾病の知識習得・向上（acquisition of therapeutic/disease knowledge） & 1 & 2 & 3 & 4 & 2.90 \\
\hline 11 & 調剤などの基礎習得（acquire basics of dispensing, etc.） & 1 & 2 & 3 & 4 & 3.01 \\
\hline 12 & 達成感度（feeling of achievement） & 1 & 2 & 3 & 4 & 2.78 \\
\hline
\end{tabular}


斐のあることである. 後期のフィードバックでは, 学生は，ポスター作り $(29 \%)$, PSE 話すこと (14.5\%), 及びポスターを使用する PSE での口頭 発表（16.9\%）の学習ができたとの報告とともに,

発表スキル $(14.5 \%)$ 及び自信 $(11.4 \%)$ の向上を 報告するものも何人かいた，また，質疑応答（特に 質問に答える場合）については，なお改善の余地が 残されているものの，質問することを学んだ者や質 問の答えを考えることを学んだという者もいた.

4 年次 : 前期（PSE-4A）は, 公表論文の発表を 取り扱っており, これまでに, 学生たちは, 読み取 り，聴き取り，戦略を練ること，ポスターを使用す る口頭発表, パワーポイント発表, 及び PSE での 意思疎通の仕方を学習するプロセスを完了してい る．全員が，PSEを読む，聴く，話す，及び書く 際の自立心と言語能力向上を達成したわけではない が，ほとんどが，十分高い水準を達成して国際舞台 で使用するために，これら 4 つの言語要素で早いス タートを切ることができる，確かに，前もって作成 したメモを見ないで研究結果を発表できた学生もい た.

学生たちは, SSTSEE システムの究極目標の $1 つ$ である国際学会での発表に匹敵する熟練した発表を 行っていた. ${ }^{46)} 4$ 年次の後期（4B）では, OTC 薬 及び処方箋薬の調剂についてのロールプレーの結果 は満足できるものであった。フィードバックによる と，学生は，ドラッグストア, ${ }^{33,34)}$ 薬局あるいは病 院 35,36$)$ での顧客あるいは患者との接し方について適 切な準備ができたと評価している，彼らは，さらに，

PSE-4B のセッションが objective structured clinical examination（OSCE）に挑戦する際に有用であり, 5 年次に実務実習を行うことを目指している学生に とって有益であることを知った，学生達は, きっと 現場でも本講義の有用性を実感するものと思われる.

\section{薬剤師及び研究者になるためのプログラムの意義}

4 年間にわたつて本プログラムを受けた学生達は, 5 年次に行う薬局や病院で実習の心構えができたこ とであろう. 4 年間のコースを誠実に熱心に受講し た学生達は, 国際学会での研究結果の発表そして薬 局や病院でプロの薬剤師としての業務を遂行するこ とができることであろう.

SSTSEE システムは，彼らが言語の壁を乗り越え る手段を提供する。患者（特に，英語しか理解でき
ない患者）に治療や薬の使用について相談や助言を する場合に手段を提供する。目本人のほかにも，本 システムは, 非英語圈の薬学生にも効果的である. それは, 本システムが能動的深層的学習 (activeplus-deep learning) だからである.

学生は, SE を使用して人前で話すことで, プロ として意思疎通の自信を育み，自身の視点を考察す る. 自らのアイデアや立場を支えるための傍証を求 めたり，適切な方法で質問したり，答えたり，自分 たちの考えや結論を書き留めたりする一方で，チー ムワークの精神を忘れることなく効果的に研究結果 を生み出していく.

もつと高レベルを求めて, 大学院で研究業務を志 す者にとって，この SSTSEE システムは，SE・ PSE による意思疎通の基礎を提供し，国際舞台で その後自信をもって自分たちの研究結果を広めるこ とを助けるものである．英語を話す海外の国々で大 学院（卒業後）の研究を続けることは，もはや夢で はなくなった。

\section{教育は，講義室を超えるものである}

私は, 3 学年にわたって学部学生 (3 年次後期, すなわち PSE-3B から卒業まで）を育成するという 機会を得ることができた，私の初めての研究室分属 は, 2012 年度にスタートし, 最後の第 3 回目は, 2014 年 9 月であった。学生が, 私の研究室に分属 になり，週に 1 回あるいは 2 回のペースで本を読ん だりして，公表論文を読んでセミナーを行い，SE 及びPSE を使用して彼らの研究結果や考えを発表 した，学生たちは，セミナーでの発表のために免疫 学, 心理学, 行動学, 及び予防薬のような私たちの 研究内容に関連する文献を選んで勉強した。 さらに 彼らは, 私の国際学会で発表するためのデー夕解析 等を手伝う中でも多くを学んだ.

読んで訓練するという日常業務は，5年次の実習 (臨床で薬剂師の見地から死亡例を観察することが できた）の間の経験を介し，私自身や学生によって 行動生理 ${ }^{48)}$ 及び臨床 ${ }^{49,50)}$ 的見地にまで拡大した。私 の学生には,すべて少なくとも 1 回は, 国際学会 （例えば 2014-2015 年）でポスターや口頭発表 （Fig. 8）をする機会を与えた。彼らには，時間と 機会があれば，海外で語学を学ぶことを推奨し た. ${ }^{51)}$

学生達は, 国際学会での発表 ${ }^{52}$ のための海外旅行 


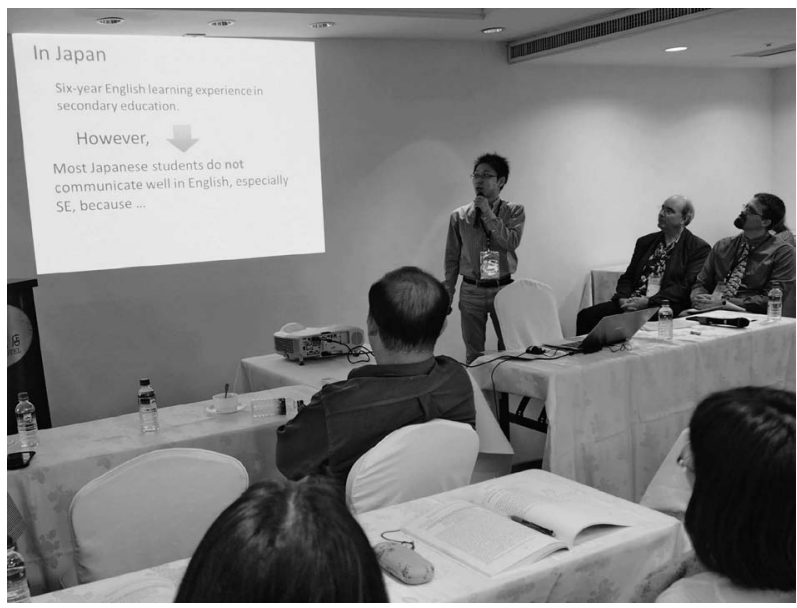

Fig. 8. A Student (class of 2015) Presents Findings from Our Department Using Power-point at an International Conference in Taipei

の間，日常会話を上手に話すことはできたが，SE 及びPSE を用いる意思疎通においては，いまだ改 善の余地があった。大学カリキュラムとして有用で 新たな情報を学ぶ一方で, 学んだことを実行に移す 場合に，十分（70-80\%ほど）にPSEの成果を発揮 することができた。したがって，私は，自分の研究 室の学生やその他の希望する京都薬科大学の学生を PSE 使用して薬局の商品を製造する実習コースに 参画させることでさらに学ばせた。2015 年度に は，希望する 4 人の男子学生を集め, 海外の大学で の実習を体験させることができた. ${ }^{53)}$

私たちは，実験室での作業に 3 日間，営業中の薬 局での日常業務の観察に 1 日を使った。最後の 2 日 間は，現地での歴史と文化サイトを訪ねて過ごし

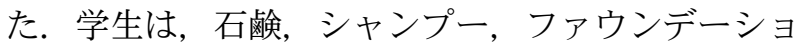
ンクリーム，及びロ紅のような化粧品の製造につい て学んだ．大変優秀な者がいる一方で，技術に改善 の余地を残す者もいたが，できたものはオリジナル であった，学生たちは，国際学会の費用を自費で工 面した。彼らが，学会や実習に参加するために，ア ルバイトをしていたのはとても印象的であった。学 生達を実習に参加させ，学会で研究結果を発表させ ることは, 彼らの成長を助ける重要な方法である. さらに, 彼らを他施設, 他国, 異文化出身の人々と 対話させ，個人の誠実さを向上させ，グローバルな 考え方を養成し，人間関係を形成し，多方面にわ たつて，均整の取れた個人へと彼らを変えることを 可能にすることによって彼らを外界に触れさせるこ
とは重要である，結局，薬剤師である前に，学生た ちは，何よりもまず，この広い世界で生きる人間で ある。

今まで SSTSEE システム ${ }^{21)}$ は, 京都薬科大学で 開発されてきたが，私のただ 1 つの願いは，京都薬 科大学とその学生が，本プログラムを信じ，学習を 継続することであり，その結果，過去にはみられな かつたような卒業生を将来送り出し続けることであ る.

日本での開催が予定されている 2020 年の第 31 回 オリンピックは，日本の薬剤師が役に立つ貴重な機 会である. 自信と誇りをもって責任を果たして頂き たい。この機会を活かして, 薬剤師全員が, 必要と されるすべての人々の医療に役立ち，製品を開発 し，「新しい」日本の進歩的かつグローバルなイメー ジを伝えるために最善を尽くしてもらいたい。日本 の未来に栄光あれ。

謝辞 この論文の作成に当たり, 京都薬科大学 基礎科学系薬学英語分野の学生諸君の協力にお礼を 申し上げます。また，和文作成・校正などに御協力 を頂きました中井久郎先生に感謝いたします。

利益相反＼cjkstart開示すべき利益相反はない.

\section{REFERENCES}

1) Foong F. W., Kyoyakuronshu, 17, 41-46 (2010).

2) Fujiwara Y., J. Acad. Soc. for Quality of Life, 2(1) 5, 1-3 (2016).

3) Barnes D. R., Britton J. N., Rosen H., “'Language, the Learner and the School," Penguin, Harmondsworth, 1971.

4) Garner P. L., The Australian Science Teachers' Journal, 20 (1) , 63-76 (1974) .

5) Muralidhar S., Res. Sci. Edu., 21, 253-262 (1991).

6) Welling J. J., Osborne J., "Language and Literacy in Science Education," Open University Press, Buckingham-Philadelphia, 2001.

7) Lemke J. L., "Talking Science: Language, Learning and Values," Ablex, Norwood, 1990.

8) Fang Z., Schleppegrell M. J., "Reading in Secondary Content Areas: A Language-based 
Pedagogy,' University of Michigan Press, Ann Arbor, 2008.

9) De Oliver L. C., Dodds K. N., Electronic Journal of Literacy through Science, 9(1) , 114 (2010).

10) “Comprehensive Scientific English A,' 2nd ed., ed. by Foong A. F. W., Imex Japan, Kyoto, 2012.

11) "Scientific English: Intermediate Level A," 2nd ed., ed. by Kawamura Y., Ito Y., Foong A. F. W., Imex Japan, Kyoto, 2009.

12) "Basic English Communication for Pharmacists I,', 2nd ed., ed. by Foong A. F. W., Imex Japan, Kyoto, 2008.

13) "Basic English Communication for Pharmacists II,’’ ed. by Foong A. F. W., Sasa M., Imex Japan, Kyoto, 2008.

14) "Fundamentals in Scientific Writing: All in One," ed. by Akaike A., Kimura K., Foong A. F. W., Imex Japan, Kyoto, 2007.

15) “Basic Scientific English IA,' 3rd Ed., ed. by Foong A. F. W., Sato E., Imex Japan, Kyoto, 2014.

16) “Basic Scientific English IB,' 3rd ed., ed. by Foong A. F. W., Sato E., Imex Japan, Kyoto, 2016.

17) “Useful Pharmaceutical English,” 2nd ed., ed. by Foong A. F. W., Kamada M., Hibino K., Nakai H., Imex Japan, Kyoto, 2014.

18) “Practical Pharmaceutical English,', 2nd ed., ed. by Foong A. F. W., Nakai H., Matsuda H., Kamada M., Imex Japan, Kyoto, 2014.

19) Foong F. W., Fujiwara N., Fujita A., Fujimori Y., Inoue Y., Higuchi Y., GSE Journal of Education, 207-212 (2013).

20) Science English Seminar by Prof. Foong, KPU News, 170, 14-15 (2012).

21) Foong F. W., Farumashia, 50, 784-788 (2014).

22) Foong F. W., Farumashia, 50, 900-902 (2014).

23) Foong F. W., Farumashia, 51, 53-55 (2015).

24) Foong F. W., Farumashia, 51, 150-152 (2015).

25) Foong F. W., Farumashia, 51, 571-574 (2015).

26) Foong F. W., Higuchi Y., Hirai A., Fujita A., Fujiwara N., Okamori S., GSE Journal of Education, 200-206 (2013).
27) Foong F. W., Farumashia, 51, 692-695 (2015).

28) Foong F. W., Farumashia, 51, 795-798 (2015).

29) Foong F. W., Farumashia, 50, 1009-1011 (2014).

30) Foong F. W., Farumashia, 50, 1137-1139 (2014).

31) Foong F. W., Farumashia, 51, 248-250 (2015).

32) Foong F. W., Farumashia, 51, 352-355 (2015).

33) Foong F. W., Farumashia, 51, 879-881 (2015)

34) Foong F. W., Farumashia, 51, 983-985 (2015).

35) Foong F. W., Farumashia, 51, 1173-1176 (2015).

36) Foong F. W., Farumashia, 52, 66-67 (2016).

37) Foong F. W., Ogasawara H., Noguchi A., Hasegawa K., Matsuno H., Wajima R., J. Acad. Soc. for Quality of Life, 1(3), 6-9 (2015).

38) Foong F. W., Matsuno H., Ogasawara H., Noguchi A., Hasegawa K., Wajima R., J. Acad. Soc. for Quality of Life, 1(1), 21-25 (2015).

39) Nishika Y., Sato E., Foong F. W., J. Acad. Soc. for Quality of Life, 1 (4) , 40-46 (2015).

40) Sato E., Nishioka Y., Foong F. W., J. Acad. Soc. for Quality of Life, 2(1) 3, 1-8 (2016).

41) Foong F. W., Sato E., J. Acad. Soc. for Quality of Life, 2(1) 4, 1-11 (2016).

42) Foong F. W., Fujiwara Y., Sato E., J. Acad. Soc. for Quality of Life, 2(2) 2, 1-11 (2016).

43) Foong F. W., Farumashia, 52, 552-555 (2016).

44) Foong F. W., Farumashia, 52, 688-691 (2016).

45) Foong F. W., Farumashia, 52, 788-791 (2016).

46) Foong F. W., Wajima R., Matsumoto H., Hasegawa K., Ogasawara H., J. Acad. Soc. for Quality of Life, 1(1), 16-20 (2015).

47) Foong F. W., Farumashia, 52, 169-172 (2016).

48) Foong F. W., J. Acad. Soc. for Quality of Life, 1 (4) , 47-48 (2015).

49) Foong F. W., J. Acad. Soc. for Quality of 
Life, 2 (3) 5, 1-3 (2016).

50) Noguchi Y., Foong F. W., J. Acad. Soc. for Quality of Life, 2(3) 3, 1-6 (2016).

51) Foong F. W., KPU News, 176, 9-11 (2014).
52) Foong F. W., Higuchi Y., KPU News, 180, 14-15 (2015).

53) Foong F. W., Higuchi Y., Sakano H., Shima K., Yagi T., KPU News, 182, 14-15 (2015) . 